NASA Contractor Report 202351

$1 N-07$

040920

AIAA-97-3139

\title{
Design of the NASA Lewis 4-Port Wave Rotor Experiment
}

Jack Wilson

NYMA, Inc.

Brook Park, Ohio

June 1997

Prepared for

Lewis Research Center

Under Contract NAS3-27186

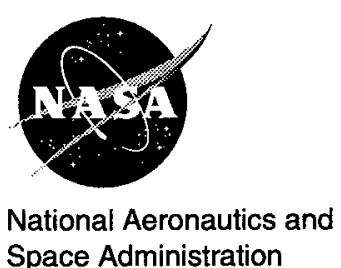

Space Administration 


\title{
DESIGN OF THE NASA LEWIS 4-PORT WAVE ROTOR EXPERIMENT
}

\author{
Jack Wilson* \\ NYMA, Inc. \\ Brook Park, Ohio 44142
}

\begin{abstract}
$\underline{\text { Abstract }}$
Pressure exchange wave rotors, used in a topping stage, are currently being considered as a possible means of increasing the specific power, and reducing the specific fuel consumption of gas turbine engines. Despite this interest, there is very little information on the performance of a wave rotor operating on the cycle (i.e. set of waves) appropriate for use in a topping stage. One such cycle, which has the advantage of being relatively easy to incorporate into an engine, is the four-port cycle. Consequently, an experiment to measure the performance of a four-port wave rotor for temperature ratios relevant to application as a topping cycle for a gas turbine engine has been designed and built at NASA Lewis. The design of the wave rotor is described, together with the constraints on the experiment.
\end{abstract}

\section{Nomenclature}

P stagnation pressure

$\mathrm{T}$ stagnation temperature

\section{Suffixes}

1 inlet port

2 outlet to heater

3 return from heater

4 exhaust port

Introduction

At NASA Lewis, wave rotors are being investigated for use in a topping stage for gas turbine engines in order to increase performance while maintaining temperatures in rotating components at levels used in current technology. The primary application considered is aircraft propulsion or auxiliary power. Calculations have shown that increases in specific power of $\sim 20$ percent, and reductions in specific fuel consumption of $\sim 15$ percent are possible. ${ }^{1,2}$ The original intended use of the wave rotor was as a topping stage for ground-based power units, ${ }^{3}$ and a recent experi-

*Senior Member. ment ${ }^{4}$ has demonstrated that large improvements in efficiency and power are possible for that application. In the configuration used by Zauner et al., ${ }^{4}$ the power generated by the topping stage was extracted by an additional power turbine, with its own shaft. Thus the power unit with a wave rotor topping stage is more complex than a power unit without the topping stage.

For aircraft engines, a simpler, and therefore preferable, configuration would be to have the extra power appear as increased pressure at the entrance to the turbine. This arrangement is illustrated in Fig. 1, and uses a fourport cycle. Figure 1(a) is a schematic diagram of an aircraft gas turbine engine. In Fig. 1(b), this same engine has been modified by adding a wave rotor. Air from the engine compressor enters the wave rotor at station 1 , and is further compressed inside the wave rotor. The compressed air leaves the wave rotor at station 2 , and passes to the burner. Combustion therefore takes place at a higher pressure than in the engine without the wave rotor. From the burner, the gas re-enters the wave rotor at station 3 , expands, and leaves the wave rotor at station 4 , passing to the engine turbine. This gas is now at higher pressure than the gas entering the turbine in the engine without a wave rotor, even though the temperature is the same. Thus more work can be extracted from the gas in the engine with a wave rotor. Admittedly, a new turbine will be necessary to handle the increased pressure ratio, but the engine configuration is essentially unchanged. Note that the same result could be achieved by adding a conventional high spool to the engine. However, if the main turbine is already close to a material temperature limitation, then the high spool would have a very high turbine inlet temperature, above present material limitations. With a wave rotor topping stage, the rotor is cooled by the relatively cool air from the compressor, and does not attain excessive temperatures.

An investigation of an application of a wave rotor topping stage to an existing aircraft engine, using a fourport wave rotor cycle, has been reported by Snyder and Fish. ${ }^{5}$ The performance of the engine with the wave rotor

"Copyright $\odot$ by the American Institute of Aeronautics and Astronautics, Inc. No copyright is asserted in the United States under Title 17, U.S. Code. The U.S. Government has a royalty-free license to exercise all rights under the copyright claimed herein for Governmental Purposes. All other rights are reserved by the copyright owner." 
topping stage depends on the performance of the wave rotor itself, which in this context means the pressure ratio developed across the wave rotor as a function of the temperature ratio across it, i.e. P4/P1 versus T4/T1. There appear to be only two investigations of four-port wave rotor performance, by Klapproth et al., ${ }^{6}$ and Ruffles. ${ }^{7}$ There is a significant discrepancy between these two reports, and neither is very complete. There is thus a need for detailed measurements of four port-wave rotor performance. In addition, such measurements are needed in order to validate numerical simulations so they can be used for future predictions with confidence. The measurements will also verify that the rotor does indeed remain at reasonable temperatures. An experiment to make such measurements has been designed and built at NASA Lewis Research Center. Details of the experimental scheme are described in this paper.

\section{Design of the Experiment}

\section{Physical Parameters}

If a wave rotor is to be installed in an engine as shown in Fig. 1, the temperature ratio across the wave rotor is fixed by the engine temperatures, i.e., the temperature entering the wave rotor is the compressor exit temperature, and the temperature leaving the wave rotor will be the turbine inlet temperature. Values of the compressor exit temperature, the turbine inlet temperature, and their ratio are given in Table I for several engines.

As will be seen, the design ratio of the turbine inlet temperature to the compressor exit temperature is between 1.7 and 2.3. This then is the minimum range of temperature ratios to cover in the experiment. Lower values are also needed for off-design performance.

The maximum temperature in the cycle (at the exit from the heat source) will scale with the inlet temperature, and the heating power required will scale with the mass flow and the difference between the inlet and exit temperatures. For a fixed mass flow, as the inlet temperature is raised, the maximum cycle temperature, and the required heater power also increase. The wave rotor performance depends on temperature ratio, not absolute temperature, and so a low inlet temperature can be used to avoid high maximum temperatures, and high heater powers. Three schemes to achieve this are shown in Table II, for a mass flow of $1.5 \mathrm{lb} / \mathrm{sec}$, and a temperature ratio of 2.5 , which is the maximum temperature ratio anticipated for the experiment. The mass flow was set by the available air supply in the laboratory. Fortuitously, it gives approximately the same corrected flow as would enter the wave rotor in an engine generating about $500 \mathrm{hp}$. In scheme A, a low inlet temperature is achieved by spraying liquid nitrogen into the air supply. While a low inlet temperature can be created this way, this scheme does require a lot of liquid nitrogen, which is expensive. In scheme $\mathrm{C}$, atmospheric air is used as the supply gas. This requires a fairly large heater. Worse is that it creates high temperatures in the rotor, with an estimated rotor temperature of $1000^{\circ} \mathrm{R}$. This temperature is too high for the rotor design chosen. Scheme $B$ avoids the high temperatures of scheme $\mathrm{C}$ by using air chilled to $400^{\circ} \mathrm{R}$ as the supply air, and the heater power required is not much more than for scheme A. Fortunately, NASA-Lewis has a chilled air supply. In addition, a Caloritech T90-2444 electric heater with a $350 \mathrm{~kW}$ rating was available. Consequently, scheme B was selected. Although a burner would have provided a more compact and realistic source of heat, no suitable burner was available, and so the electric heater was chosen. Use of a heater rather than a burner has an advantage and a disadvantage. The advantage is that it corresponds to the currently available codes, which are limited to a single value of the ratio of specific heats. This is simultaneously its disadvantage, in that a burner would produce a gas with a ratio of specific heats more appropriate to that produced in an engine, and therefore more true to life.

\section{Rotor Optimization}

Originally, the intention was to use the rotor from a prior experiment. ${ }^{8}$ However, calculations using a onedimensional wave rotor CFD code ${ }^{9}$ showed that the output pressure would be quite low. This is due to the small passage height of the previous rotor, which leads to both large frictional and large leakage losses. Consequently, it was decided to build a new rotor, and to try to optimize the output pressure. The optimization procedure has been described previously, ${ }^{1}$ and will not be repeated here. The rotor was optimized for a ratio of $\mathrm{T} 4 / \mathrm{T} 1$ of 2.0 , at a mass flow of $1.5 \mathrm{lb} / \mathrm{sec}$. The resulting rotor dimensions are: rotor average diameter; 6.7 in., rotor length; 10.5 in., passage height; $1.3 \mathrm{in}$., and passage width; 0.65 in. A photograph of the rotor is given in Fig. 2. The rotor was constructed from titanium, and the passages were first drilled, then electric-discharge machined to final shape. The rotor is turned by a variable speed electric motor governed by a constant speed controller to allow selection of any desired speed.

\section{Port Timing}

The cycle of a wave rotor is conveniently described in a wave diagram, ${ }^{10}$ which is a plot of the trajectories of the waves in time and position along a passage, as it rotates through one revolution. The wave diagram for the fourport cycle of the present experiment at $\mathrm{T} 4 / \mathrm{T} 1=2.0$, as calculated with the one-dimensional CFD code, ${ }^{9}$ is given in Fig. 3. This CFD code has been validated against the three-port wave rotor experiments of Ref. 8, and other experiments. The timing of the cycle, i.e. when the ports open and close, was determined from the wave diagram. 
The leading edges of the inlet ports (ports 1 and 3) were rounded to minimize opening losses. ${ }^{11}$

The ducts bringing the air on or off the rotor were set at the correct angle for the flow to enter or leave the rotor aligned with the axis in the rotor reference frame. They were shaped to give a gradual transition from a circular cross-section at the end furthest from the rotor to the appropriate section of an annulus at the rotor face. Figure 4 is a photograph of a duct.

\section{Instrumentation}

Figure 5 is a schematic view of the experiment. A diagnostic spool is installed at the outer end of each duct, with three static pressure taps, plus a rake with five total pressure probes (each at a different radial location) and two thermocouples. From these pressure and temperature measurements, the radial velocity distribution can be found, and hence an average total pressure, at each duct. Similar spools were installed at the entrance to, and exit from, the heater. Tube-type combination pressure probes ${ }^{12}$ are used in the inlet port to measure flow direction, and, in conjunction with wall static taps, velocity. In the other ports, rakes with five pitot probes, together with wall static pressure taps, are used to give radial velocity distributions. Five such rakes are used in the exit port. The resulting circumferential and radial velocity distributions are used in a mixing calculation ${ }^{13}$ to give the exit average total pressure $\mathrm{P} 4$. In addition, thermocouples are used to give temperatures at different circumferential locations. In the exit leg, a temperature spool, with nine thermocouples, each sampling an equal section of the spool area, with the resulting signals electronically averaged, is used to give the exit temperature T4.

Dynamic pressure transducers are mounted on the rotor, with the signals taken out through a slip ring, to give pressure histories at each end of a passage as it goes through a cycle. Thermocouples are also mounted on each end of the rotor to give the rotor temperature, and the signals also taken out through the slip ring.

\section{Experimental Plan}

The results of the prior experiments of Klapproth et al. ${ }^{6}$ and Ruffles, ${ }^{7}$ are given in Fig. 6. Also given in Fig. 6 is a prediction of the results obtained with the CFD code of Paxson. ${ }^{9}$ However the calculations have made clear that the ratio $\mathrm{P} 4 / \mathrm{P} 1$ does not depend on the temperature ratioT4/T1 alone.

It is also affected by the rotor speed, and the expansion ratio, which is the ratio of static pressure in the outlet port 4 to the pressure in a passage immediately before it opens to port 4 . The expansion ratio controls the mass flow rate through the machine. In running the experiment, a value of $\mathrm{T} 4 / \mathrm{T} 1$ will be set, and maintained, and sets of measurements made in which the expansion ratio is varied, at various values of the rotor speed. This will give data from which the optimum P4/P1 versus T4/T1 for this rotor can be obtained. In addition, the predictions are based on a value of pressure loss in the heater loop. The experiment is provided with a position where an orifice can be inserted to vary this pressure loss, so that the sensitivity to this pressure drop can be determined, and compared with code predictions. The experiment is scheduled to commence in the summer of 1997.

\section{Conclusions}

A wave rotor experiment has been designed and built at NASA-Lewis to investigate the performance of a wave rotor operating on a four-port cycle. The rotor dimensions were optimized using a one-dimensional CFD code, which was validated against prior experiments. The experiment will be used to make performance measurements as a function of temperature ratio, mass flow, rotor speed, and heater pressure drop. These data in turn will be used to validate code results, so that future 4-port wave rotors can be designed with confidence.

\section{References}

1. Wilson, J. and Paxson, D.E., "Wave Rotor Optimization for Gas Turbine Engine Topping Cycles," Journal of Propulsion and Power, Vol. 12, No. 4, July-August, 1996, pp. 778-785.

2. Welch, G.E., Jones, S.M., and Paxson, D.E., "Wave Rotor Enhanced Gas Turbine Engines," Journal of Engineering for Gas Turbines and Power, Vol. 119, April 1997, pp. 469-477.

3. Mayer, A., "Recent Developments in Gas Turbines," Mechanical Engineering, Vol. 69, 1947, pp. 273-277.

4. Zauner,E., Chyou, Y-P.,Walraven,F., and Althaus, R., "Gas Turbine Topping Stage based on Energy Exchangers: Process and Performance," ASME 93-GT-58, Gas Turbine and Aeroengine Congress, Cincinnati, Ohio, 1993.

5. Snyder, P.H., and Fish, R.E., "Assessment of a Wave Rotor topped Demonstrator Gas Turbine Engine Concept,"ASMEPaper96-GT-41, The International Gas Turbine and Aeroengine Congress and Exhibition, Birmingham, England, 1996.

6. Klapproth, J.F., Perugi, A., Gruszczynski, J.S., Stoffer, L.J., and Alsworth, C.C., "A Brief Review of the G. E. Wave Rotor Program (1958-1963)," Proceedings of the 1985 ONR/NAVAIR Wave Rotor Research and Technology Workshop, Shreeve, R.P. and Mathur, A. Editors, Report NPS-67-85-008, Naval Postgraduate School, Monterey, CA, pp. 172-193, 1985. 
7. Ruffles, P., "Rolls-Royce Study of Wave Rotors 1965-1970," Proceedings of the 1985 ONR/ NAVAIR Wave Rotor Research and Technology Workshop, Shreeve, R.P. and Mathur, A. Editors, Report NPS-67-85-008, Naval Postgraduate School, Monterey, CA, pp. 116-124, 1985.

8. Wilson, J., "Losses in a 3-Port Wave Rotor," NASA CR-98508. Also "An Experimental Determination of Losses in a 3-Port Wave Rotor," NASA CR-198456, 1997.

9. Paxson, D.E., "Comparison between numerically modelled and experimentally measured Wave Rotor Loss Mechanisms," Journal of Propulsion and Power, Vol. 11, No. 5, Sept.-Oct. 1985, pp.908-914.
10. Rudinger, G., Wave Diagrams for Nonsteady Flow in Ducts, D. Van Nostrand Company, Inc., New York, NY, 1955.

11. Welch, G.E., and Chima, R.V., "Two-Dimensional CFD Modelling of Wave Rotor Flow Dynamics," NASA TM-106261, 1993.

12. Glawe, G.E., and Krause,L.N., "Miniature Probes for use in Gas Turbine Testing," NASA TMX-71638, 1974.

13. Foa, J.V., Elements of Flight Propulsion, John Wiley and Sons, New York, NY, pp. 161-166, 1960.

TABLE I.-GAS TURBINE ENGINE PARAMETERS

[From Jane's "All the Worlds Aircraft, 1993-1994".]

\begin{tabular}{|l|l|c|c|c|c|}
\hline Manufacturer & \multicolumn{1}{|c|}{ Model } & $\begin{array}{c}\text { Compression } \\
\text { ratio }\end{array}$ & $\begin{array}{c}\text { Compressor exit } \\
\text { temperature } \\
\text { (CET) }\end{array}$ & $\begin{array}{c}\text { Turbine inlet } \\
\text { temperature } \\
\text { (TIT) }\end{array}$ & TIT/CET \\
\hline Garrett & TPE 33 & 8 & $1006^{\circ} \mathrm{R}$ & $2268^{\circ} \mathrm{R}$ & 2.25 \\
& TFE 731-2 & 10.4 & $1094^{\circ} \mathrm{R}$ & $2300^{\circ} \mathrm{R}$ & 2.10 \\
& TFE731-3 & 14.6 & $1201^{\circ} \mathrm{R}$ & $2039^{\circ} \mathrm{R}$ & 1.70 \\
& TFE 731-20 & 14.3 & $1218^{\circ} \mathrm{R}$ & $2124^{\circ} \mathrm{R}$ & 1.74 \\
Allison & $\mathrm{T} 56 / 501$ & 9.5 & $1210^{\circ} \mathrm{R}$ & $2185^{\circ} \mathrm{R}$ & 1.81 \\
Saturn & $\mathrm{AL}-7$ & 9.1 & $1063^{\circ} \mathrm{R}$ & $2428^{\circ} \mathrm{R}$ & 2.28 \\
& $\mathrm{AL}-21$ & 14.75 & $1048^{\circ} \mathrm{R}$ & $2160^{\circ} \mathrm{R}$ & 2.06 \\
& $\mathrm{AL}-31$ & 23 & $1222^{\circ} \mathrm{R}$ & $2493^{\circ} \mathrm{R}$ & 2.04 \\
Aviadvigatel & $\mathrm{PS}-90 \mathrm{~A}$ & 35.5 & $1407^{\circ} \mathrm{R}$ & $3060^{\circ} \mathrm{R}$ & 2.17 \\
\hline
\end{tabular}

TABLE II.-POSSIBLE SCHEMES FOR THE EXPERIMENT

\begin{tabular}{|l|c|c|c|}
\hline \multicolumn{1}{|c|}{ Scheme } & $\mathrm{A}$ & $\mathrm{B}$ & $\mathrm{C}$ \\
\hline Inlet air temperature & $360^{\circ} \mathrm{R}$ & $400^{\circ} \mathrm{R}$ & $530^{\circ} \mathrm{R}$ \\
Inlet air source & $\mathrm{LN}_{2}$ sprayed into air & chilled air & atmospheric air \\
Heater power required $(\mathrm{kW})$ & 213 & 237 & 314 \\
Liquid $\mathrm{N}_{2}$ required $(\mathrm{lb} / \mathrm{sec})$ & 0.33 & --- & ---- \\
Maximum temperature & $1007^{\circ} \mathrm{R}$ & $1119^{\circ} \mathrm{R}$ & $1482^{\circ} \mathrm{R}$ \\
\hline
\end{tabular}




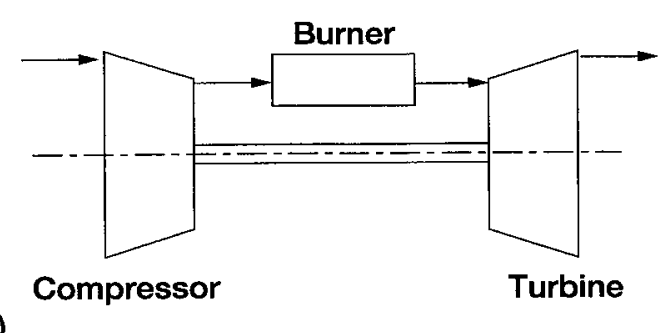

(a)

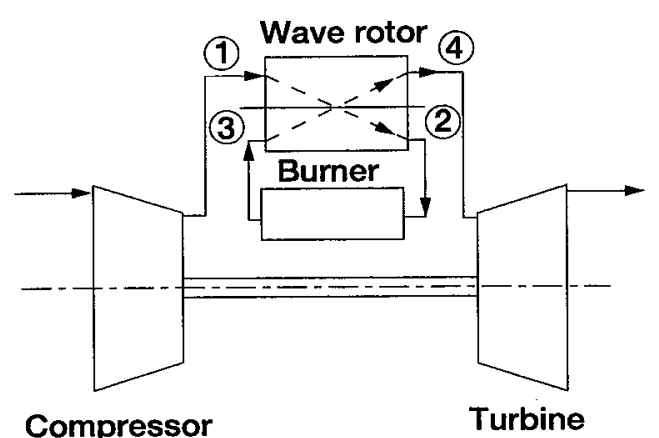

(b)

Figure 1.-Schematic diagram. (a) Gas turbine engine. (b) Gas turbine engine with a wave rotor topoina stace.

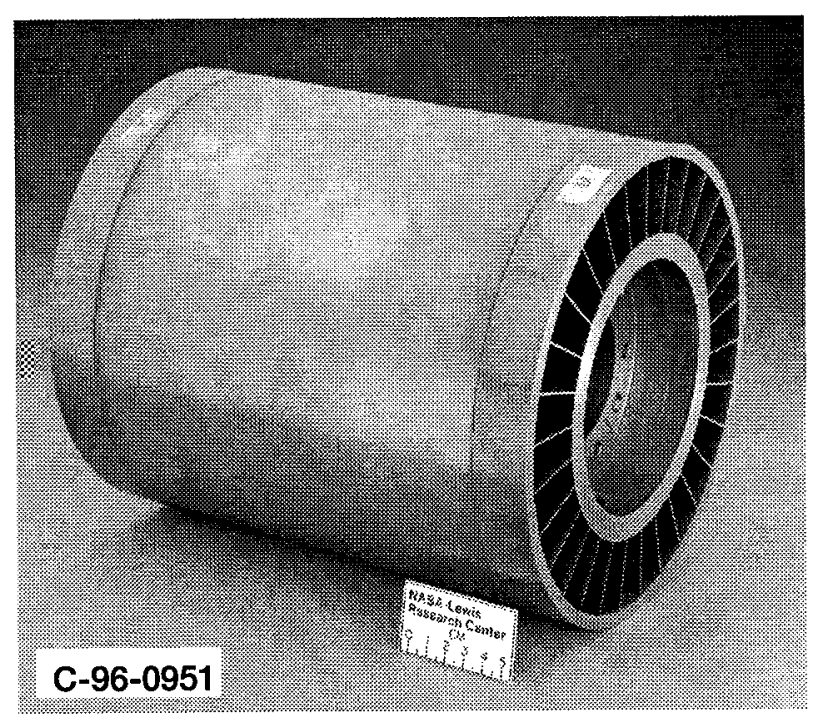

Figure 2.-Photograph of the rotor used in the experiment.

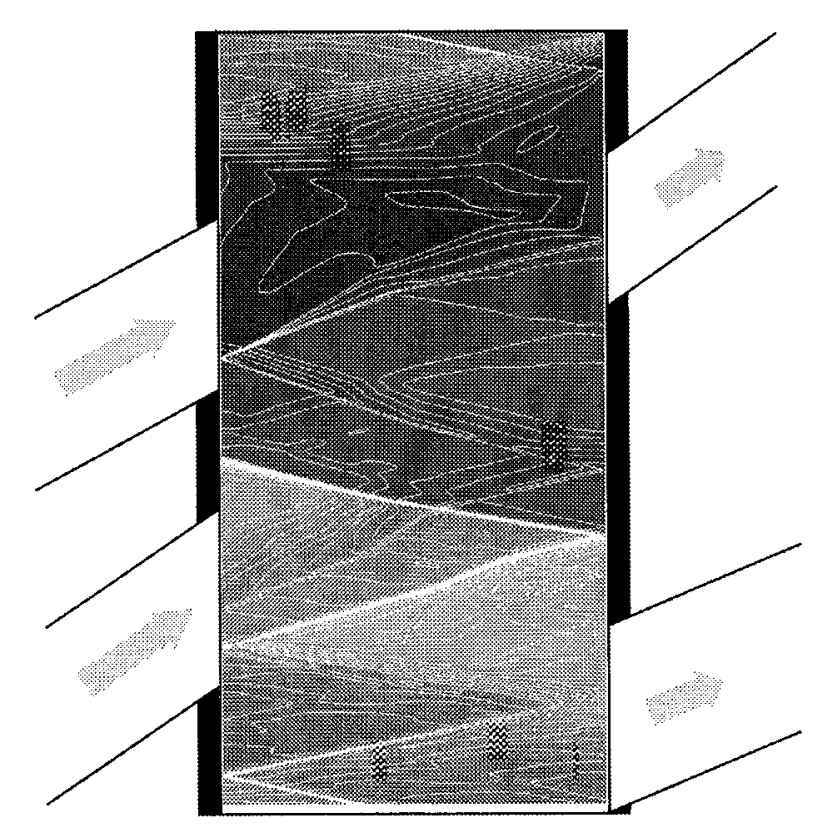

Figure 3.-The wave diagram for a four-port wave rotor cycle. The contour lines are isobars. This diagram, courtesy of D.Paxson, was calculated using the NASA-Lewis one-dimensional CFD Code for wave rotors 9 .

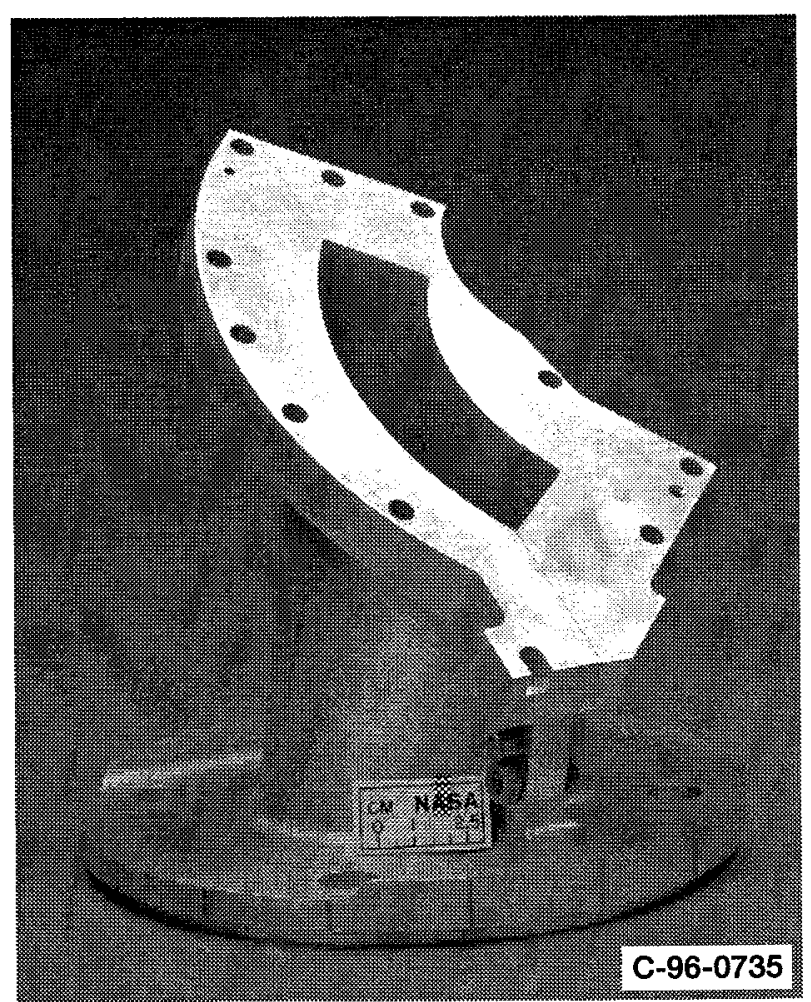

Figure 4.-Photograph of an inlet duct. 


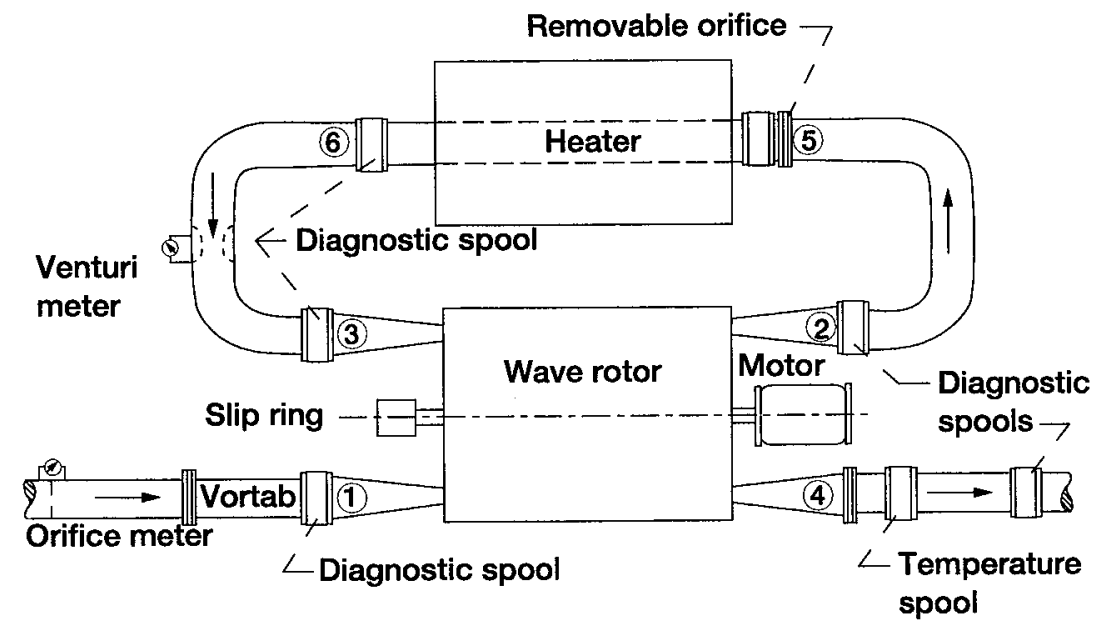

Figure 5.-Schematic diagram of the experimental arrangement. The numbers indicate the flow path as follows: 1 - inlet port, 2 - high pressure outlet going to the heater, 3 - return port bringing flow back from the heater, 4 - final exhaust port.

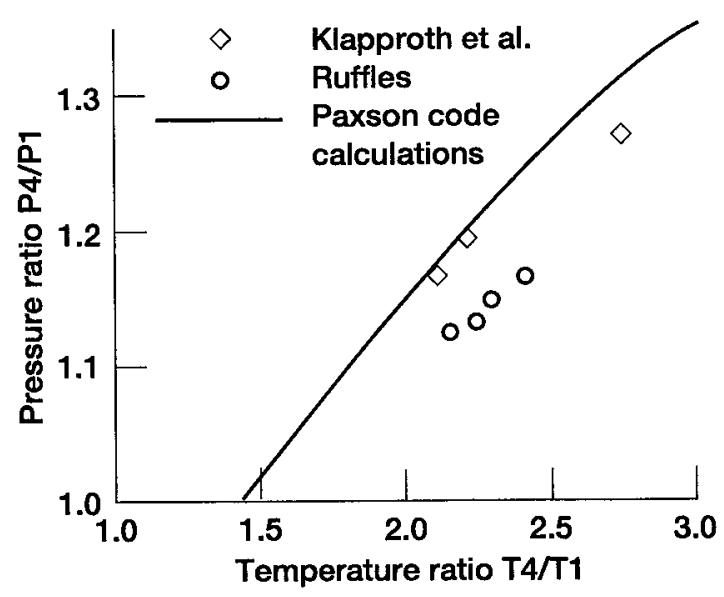

Figure 6.-Plot of wave rotor pressure ratio versus temperature ratio., showing experimental results by Klapproth et al. 6 , and Ruffles7, together with a theoretical calculation by Paxson ${ }^{9}$, using the NASA-Lewis one-dimensional CFD code for wave rotors. 


\begin{tabular}{|c|c|c|c|}
\hline \multicolumn{3}{|c|}{ REPORT DOCUMENTATION PAGE } & $\begin{array}{l}\text { Form Approved } \\
\text { OMB No. 0704-0188 }\end{array}$ \\
\hline \multicolumn{4}{|c|}{$\begin{array}{l}\text { Public reporting burden for this collection of information is estimated to average } 1 \text { hour per response, including the time for reviewing instructions, searching existing data sources, } \\
\text { gathering and maintaining the data needed, and completing and reviewing the collection of information. Send comments regarding this burden estimate or any other aspect of this } \\
\text { collection of information, including suggestions for reducing this burden, to Washington Headquarters Services, Directorate for Information Operations and Reports, } 1215 \text { Jeflerson } \\
\text { Davis Highway, Suite 1204, Arlington, VA 22202-4302, and to the Office of Management and Budget, Paperwork Reduction Project (0704-0188), Washington, DC 20503. }\end{array}$} \\
\hline 1. AGENCY USE ONLY (Leave blank) & $\begin{array}{r}\text { 2. REPORT DATE } \\
\text { June } 1997\end{array}$ & \multicolumn{2}{|c|}{$\begin{array}{l}\text { 3. REPORT TYPE AND DATES COVERED } \\
\text { Final Contractor Report }\end{array}$} \\
\hline \multicolumn{3}{|c|}{$\begin{array}{l}\text { 4. TITLE AND SUBTITLE } \\
\text { Design of the NASA Lewis 4-Port Wave Rotor Experiment }\end{array}$} & \multirow{2}{*}{$\begin{array}{l}\text { 5. FUNDING NUMBERS } \\
\text { WU-505-26-33 } \\
\text { C-NAS3-27186 }\end{array}$} \\
\hline \multicolumn{3}{|l|}{$\begin{array}{l}\text { 6. AUTHOR(S) } \\
\text { Jack Wilson }\end{array}$} & \\
\hline \multicolumn{3}{|c|}{$\begin{array}{l}\text { 7. PERFORMING ORGANIZATION NAME(S) AND ADDRESS(ES) } \\
\text { NYMA, Inc. } \\
2001 \text { Aerospace Parkway } \\
\text { Brook Park, Ohio } 44142\end{array}$} & $\begin{array}{l}\text { 8. PERFORMING ORGANIZATION } \\
\text { REPORT NUMBER } \\
\text { E-10774 }\end{array}$ \\
\hline \multicolumn{3}{|c|}{$\begin{array}{l}\text { 9. SPONSORING/MONITORING AGENCY NAME(S) AND ADDRESS(ES) } \\
\text { National Aeronautics and Space Administration } \\
\text { Lewis Research Center } \\
\text { Cleveland, Ohio } 44135-3191\end{array}$} & $\begin{array}{l}\text { 10. SPONSORING/MONITORING } \\
\text { AGENCY REPORT NUMBER } \\
\text { NASA CR-202351 } \\
\text { AIAA-97-3139 }\end{array}$ \\
\hline \multicolumn{4}{|c|}{$\begin{array}{l}\text { 11. SUPPLEMENTARY NOTES } \\
\text { Prepared for the 33rd Joint Propulsion Conference cosponsored by AIAA, ASME, SAE, and ASEE, Seattle, Washington, } \\
\text { July 6-9, 1997. Project Manager, Larry Bober, Turbomachinery and Propulsion Systems Division, NASA Lewis Research } \\
\text { Center, organization code 5810, (216) 433-3944. }\end{array}$} \\
\hline \multicolumn{3}{|c|}{$\begin{array}{l}\text { 12a. DISTRIBUTION/AVAILABILITY STATEMENT } \\
\text { Unclassified - Unlimited } \\
\text { Subject Category } 07 \\
\text { This publication is available from the NASA Center for AeroSpace Information, (301) 621-0390. }\end{array}$} & 12b. DISTRIBUTION CODE \\
\hline \multicolumn{4}{|r|}{$\begin{array}{l}\text { ssible means of increasing } \\
\text { this interest, there is very } \\
\text { appropriate for use in a } \\
\text { into an engine, is the four- } \\
\text { for temperature ratios } \\
\text { at NASA Lewis. The }\end{array}$} \\
\hline \multirow{2}{*}{\multicolumn{3}{|c|}{$\begin{array}{l}\text { 14. SUBJECT TERMS } \\
\text { Wave rotor; Gas turbine topping stage; Wave rotor performance measurement }\end{array}$}} & $\begin{array}{c}\text { 15. NUMBER OF PAGES } \\
8\end{array}$ \\
\hline & & & \begin{tabular}{r|} 
16. PRICE CODE \\
A02 \\
\end{tabular} \\
\hline $\begin{array}{l}\text { 17. SECURITY CLASSIFICATION } \\
\text { OF REPORT } \\
\text { Unclassified }\end{array}$ & $\begin{array}{l}\text { 18. SECURITY CLASSIFICATION } \\
\text { OF THIS PAGE } \\
\text { Unclassified }\end{array}$ & $\begin{array}{l}\text { 19. SECURITY CLASSIFICATION } \\
\text { OF ABSTRACT } \\
\text { Unclassified }\end{array}$ & 20. LIMITATION OF ABSTRACT \\
\hline NSN 7540-01-280-5500 & & & $\begin{array}{l}\text { andard Form } 298 \text { (Rev. 2-89) } \\
\text { sscribed by ANSI Std. Z39-18 }\end{array}$ \\
\hline
\end{tabular}

